Available online:

IMLA

http://journal.imla.or.id/index.php/arabi

Arabi : Journal of Arabic Studies,4 (1), 2019, 21-30

DOI: http://dx.doi.org/10.24865/ajas.v4i1.126

\title{
THE ROLE OF TECHNOLOGY TO SOLVE LANGUAGE LEARNING PROBLEMS: A PRACTICAL CASE OF COMMON CORE SCIENTIFIC STUDENTS
}

\author{
I. Fakhr-Eddine', M. Ait daoud ${ }^{2}$ \\ ${ }^{1}$ Université Mohammed $\mathrm{V}$ de Rabat, Morocco \\ ${ }^{2}$ Hassan II University of Casablanca, Morocco \\ E-mail :imadscience@hotmail.fr
}

\begin{abstract}
The misspellings are among the most important reasons that distort the Arabic language. It is based on the letters that are added or deleted, the words that separates or connects, the Humazat "الههزات" that are distinct, or the ones that are on one of the three soft letters. The spelling rules subject has received attention from various linguistic communities and specialized scientific commissions in the Arabic language. There have been numerous and various studies on spelling errors among students at different levels of study in a number of Arab countries. Students of educational institutions in Morocco are no exception to this phenomenon of spelling errors. The aim of our research is to shed the light on the types of spelling mistakes made in the Arabic language, how they are made and why. We used a survey that we analyzed using a statistical program to find out the cause of these mistakes, their intersecting and their frequency. Also, we suggest the establishment of a Learning Management System (LMS) based on the e-learning platform Moodle, to remedy to the problems of misspelling.
\end{abstract}

Keywords: E-learning, moodle, Arab language, misspelling, dictation

\begin{abstract}
Abstrak
Salah ejaan merupakan satu alasan terpenting yang dapat mendistorsi makna di dalam bahasa Arab. Hal ini didasarkan pada huruf yang ditambahkan atau dihapus, kata-kata yang memisahkan atau menghubungkan, humazat "الهمزات" yang berbeda atau yang ada di salah satu dari tiga huruf lunak. Isu aturan ejaan telah mendapat perhatian dari berbagai komunitas linguistik dan komisi ilmiah khususnya dalam bahasa Arab. Terdapat berbagai studi tentang kesalahan ejaan di kalangan siswa di berbagai tingkat studi di sejumlah negara Arab, tidak terkecuali siswa lembaga pendidikan di Maroko dengan fenomena kesalahan ejaan. Penelitian ini bertujuan untuk menjelaskan jenis kesalahan pengejaan yang dilakukan dalam bahasa Arab, bagaimana dan mengapa mereka dilakukan. Data Penelitian diperoleh dari survei yang dianalisis menggunakan program statistik untuk mengetahui penyebab, interseksi, dan frekuensi kesalahan ejakan. Penelitian ini menyarankan pembentukan Sistem Manajemen Pembelajaran (LMS) yang berbasis pada platform e-learning Moodle, untuk mengatasi masalah kesalahan ejaan.
\end{abstract}

Kata kunci: E-learning, moodle, bahasa Arab, salah ejaan, dikte 


\section{Arabi : Journal of Arabic Studies}

\section{Introduction}

Communication and exchange of meanings are the purpose of using and learning the language, the natural environment in which the language is acquired. The use of language in this environment is characterized by three characteristics: first, there is a need to use language in the process of communication; second, to give priority to the meaning; and third, to interact with the four language skills (listening, reading, speaking, and writing) and their integration with each others.

When a person uses the language to achieve a certain goal, he rarely pays attention to the language, but focuses his attention on the meaning he wishes to convey, while the language selection process occurs - including the choice of words and their connection in sentences and phrases - spontaneously, according to the meaning to be transferred, and language skill (Versteegh, 2014).

Accordingly, it is necessary for those concerned with Arabic language education to develop their education with pedagogy and technology by adopting language-based approaches that allow students to practice language anytime anywhere in situations similar to everyday situations in which language is used to achieve the functional and linguistic goals of language (Ellis, 2003).

The subject of this research is of a great importance, both on the level of collection and comprehension, or at the level of creativity and production within the educational system, which raises many problems and difficulties both at the level of methods and means of learning the Arabic language, or as regards to its comprehension and interpretation level for reading or listening (Sam, s. d.).

The legitimacy of the research is presented by the subject of a topic to which we have chosen a research area that is closely related to a number of aspects:

- The issue of spelling mistakes is considered to be one of the main problems in the current field of linguistics, specially the cognitive one (Hammad \& Ghulban, 2017).

- The relationship of this topic with all the other school subjects adds that this phenomenon is considered to be one of the phenomena where many sciences intervene to understand it and to find out its causes of perception. Among these sciences are linguistics, cognitive science, psychology, and neuroscience.

- This topic must be approached from a cognitive perspective point of view, with the use of all the technology devices needed to understand its mechanisms.

- The topic responds to the recent scientific and technical progress on one hand, and to the lack of analytic models that are not recent on the other hand.

All these have raised our attention to seek solution to avoid and bypass difficulties in spelling mistakes which are related to understanding and interpretation for high school students, specially common core scientific students.

\section{Related Work}

Numerous studies and researches have been conducted to analyze students' common spelling errors. The study of (Ali \& Al-Awfi, 2015) aimed to know the effectiveness of role-playing games strategy in the treatment of common spelling errors among the sixth grade female students in AlMadinah Al-Munawarah, and also to determine the common spelling errors among the students. It also aims to build the strategy of role-playing games. To achieve these goals, the researcher used the descriptive and semi-experimental methods. The study involved the sixth grade female primary students in general public schools in Medina. Also, the research society composed of primary Arabic language female teachers in Medina, to show their own point of view in determining the common spelling mistakes among the sixth grade female students and to know its causes. The research was applied on a ccount of 45 female students of sixth grade from the eighty fifth primary schoosl in Medina, and were distributed into two groups 23 students for experimental groups and taught by the strategy of role-playing games, while the other controlled group 
composed of 22 students was taught by the normal method. To collect the data, a questionnaire to determine the common spelling errors among the sixth grade female students, and a test to measure their level and the frequency they made common spelling mistakes.

The other previous study was done by Najim A. Al-Musawi, D.dawood A. Sabree, \& Salam n. Al- Gadhban (2007) aiming to find out common spelling errors with primary school students from the point of view of material and teachers of both sexes. The study defined clinical instructors article spelling of both sexes in primary schools of the Directorate General for Education Maysan province for the academic year 2005-2006. The research sample consisted of 80 teachers. 40 teachers were offered them open questionnaire, which contained the following question: What common spelling errors facing primary school students? Depending on the answers, the consistency was by way return (Test - Re Test) and reached his degree $87 \%$. Then, the questionnaire was applied on a sample original search that consisted of 40 teachers. The result was then addressed statistically. The results showed that there was a set of common spelling errors among primary school students, and based on the results, the researchers gave a set of recommendations and proposals.

The next research by Haider Mohammed Hana (2012) identified the errors in which the students of the Qur'anic Studies College were located in the performance of the connecting and cutting Humazat. The researchers determined the exploratory sample by students of the second year of Department of Sciences of the Quran and its language/University of Babylon for the academic year 2010-2011.

Meanwhile, Hamad \& Rahima (2013) identified the common spelling mistakes by the students of the faculties of education in Iraqi universities (diagnosis and treatment). The aim of the study was to prepare the exercises to deal with these errors that will be diagnosed. The researchers chose the written expression as a tool to detect these errors. The students were given freedom to write in an expressive subject. The researchers chose a random sample consisting of 194 students. The common spelling mistakes were subsequently extracted, and then classified, and processed statistically. The researchers were able to draw conclusions and recommendations, suggestions, and prepared in the light of errors exercises and exercises to remedy these errors.

Auday (2013) tried to answer "What are the spelling mistakes which the students of the Arabic language department, college of education, university of Karbala made?". The sample of the research was 150 students and it formed \% 28.63 from the total research community. The researcher depended on the research tool which was used by Segaab in 2002 as a tool to his research. According to the results, the researcher recommended the following instructions: 1) College instructors should notice what their students write and warn them of the spelling mistakes which they commit wherever they appear and chase those mistakes and correct them and so on, 2) Punish the students for their spelling mistakes which they commit especially in the terms exams by discounting some scores and rewarding the students who write writings without spelling mistakes by adding some marks. This built a kind of competition among the students.

These above-mentioned studies showed that the issue of misspelling in Arabic language has attracted many sholars' attention. However, most of studies only analyzed and classified the mistakes made by the students. Our study has focused on correcting the spelling mistakes to a group of common core students, males and females. Therefore, to determine the most common spelling mistakes, we decided to dictate a text to those students and to correct it. Thus, after the correction of 122 papers of the students, we were able to take a clear idea about the topic.

\section{Method}

Many teachers, parents and those interested in education are aware of the low level of pupils and students in Arabic, especially in the first stage of secondary education (Qaisi, 1988; Shibail, 2017). This weakness is extended to other studying subjects. The student gaps in the Arabic 


\section{Arabi : Journal of Arabic Studies}

language influences his level in the rest of the studying subjects, which are teaches in Arabic such as: life and earth sciences, mathematics, physics, etc.

This has led us to examine the common phenomenon of "spelling errors" in the students' writings, by using a survey that contains a number of questions that concerns some aspects of the students' life.

Materials and methods should make readers be able to reproduce the experiment. Provide sufficient detail to allow the work to be reproduced. Methods already published should be indicated by a reference: only relevant modifications should be described. Do not repeat the details of established methods.

\section{Participants}

The surveyed population consisted of common core scientific students in a public school of Casablanca-Morocco. Our sample consisted of 122 students. We found out that our sample contains more female students than male students (57\% female, $43 \%$ male) as shown by the following graphic representation:

\section{Measures}

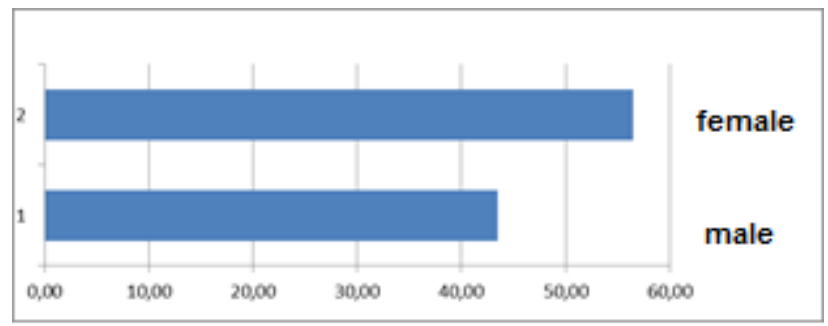

Fig. 1 : Gender Distribution

The survey was organized into 5 themes, and contains a number of questions that concerns some aspects of the students' life and, such as family and educational issues. The students were asked to answer explicitly and freely on the survey, using the website that was made especially for this study.

\section{Procedure}

The survey was conducted in 2015/2016 school year. The questionnaires were accessible via the website that was made using a free and open source on-line statistical survey web app "LimeSurvey" (Schmitz \& others, 2012). This allows us to publish our questionnaire, on the web or mobile phones, to collect responses.

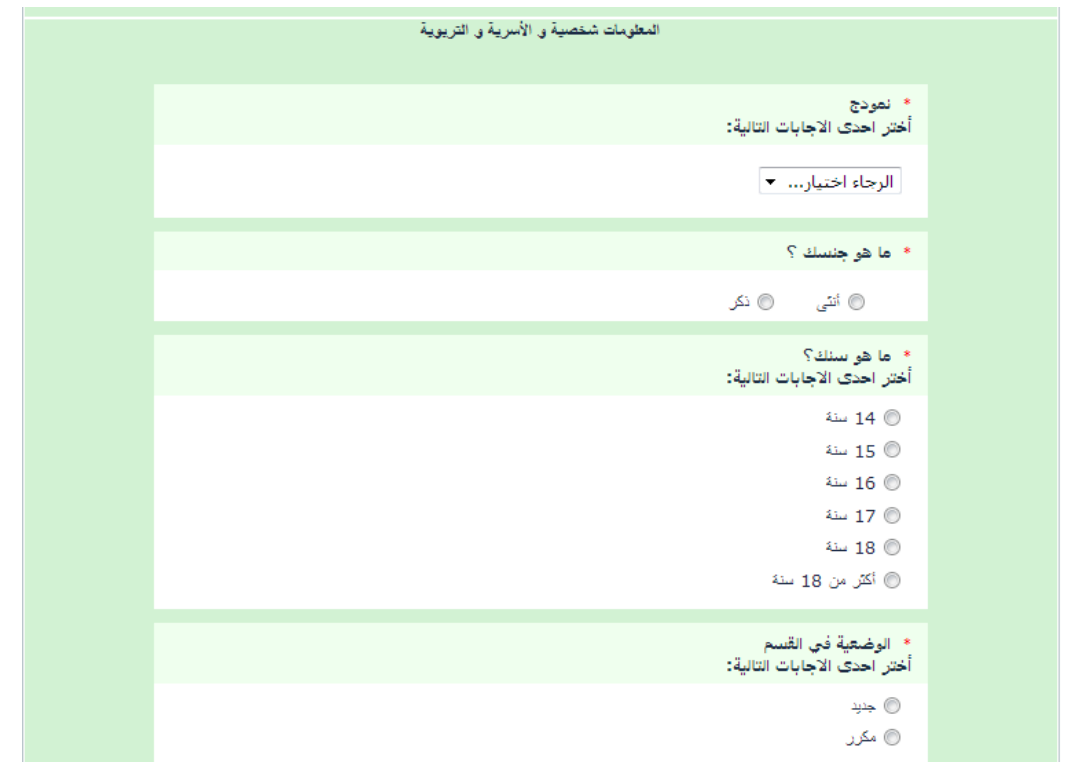

Fig. 2: The survey. 


\section{Analysis}

After data collection, we used SPSS software for data processing and analysis. SPSS (IBM, 2013) is the acronym of "Statistical Package for the Social Science". It is one of the most popular statistical packages which can perform highly complex data manipulation and analysis with simple instructions. It is designed for both interactive and non-interactive (batch) uses.

\section{Result and Discussion \\ Manifestations of making spelling mistakes in Arabic languages}

Our research revealed that the most common spelling mistakes within the common core students are those related to different kinds of Humazat "الههزات", also they are confused between the "T tethered التاء المربوطة" and the "T opened التاء المفتوحة", and the least common spelling mistakes are those of inversing the letters. It seems that the causes of those spelling mistakes are many and intervene with each other.

\section{Housing, health and family ties}

We come to conclude from the figure 2 , that the answers of the students were different according to the housing type. The students who reside in the booth are the most to commit mistakes of writing Hamzat in the middle or the last of the word, followed by the respondents who live in an independent dwelling. Meanwhile, we noticed that the students who live in a house or a shared apartment commit fewer mistakes.

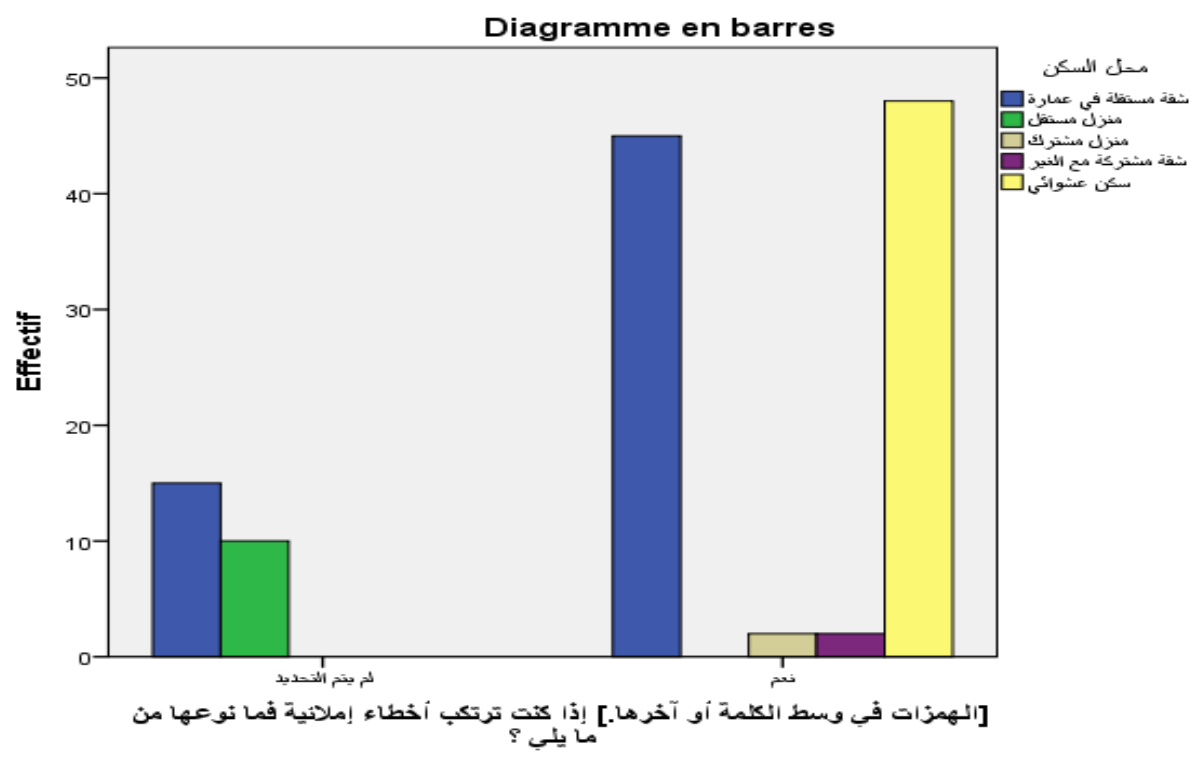

Fig. 3: The degree of impact of the housing situation of the respondents on their completion of exercises Hamzat middle word and the latest

\section{Students' relationship with the use of the Internet}

The figure 3 clearly shows that most of those students do not have a computer or internet, this does not mean that those students do not use the internet, they use it frequently at school. 


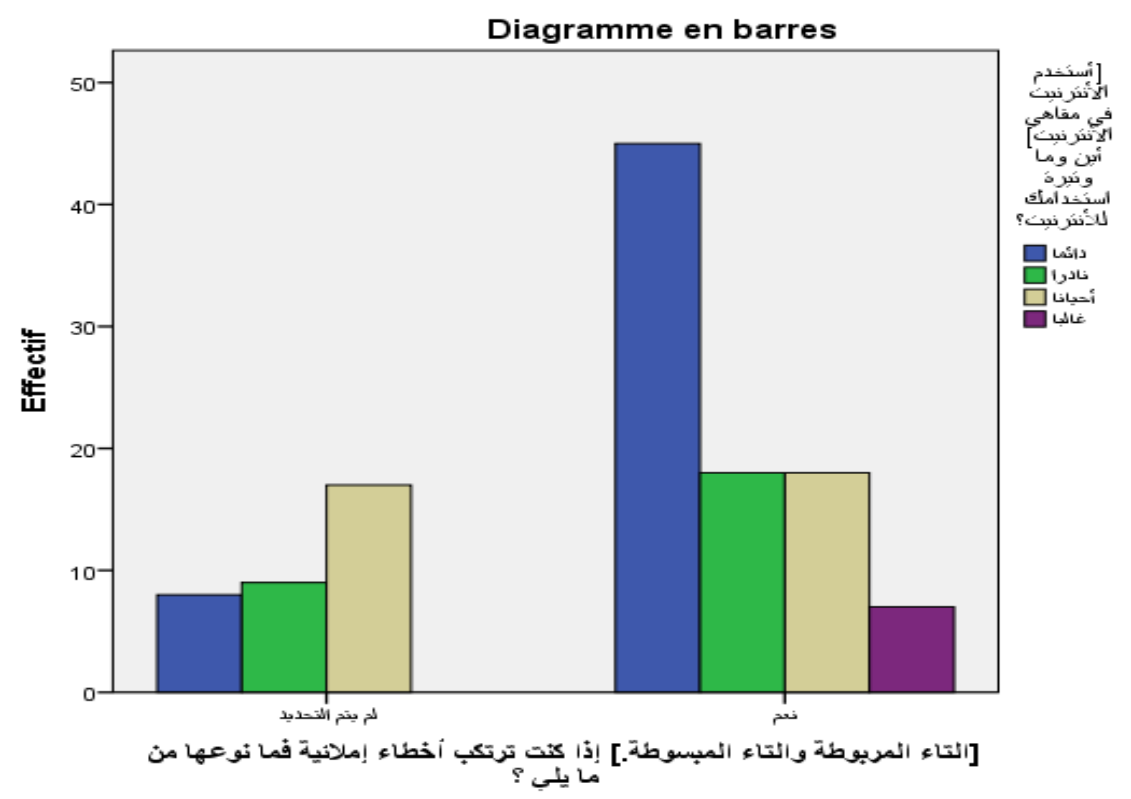

Fig. 4: the frequency of using the Internet by students

\section{Personal, family and educational information}

We come to conclude from the figure 4 that most students who confuse between similar sounds and similar letters in shape are those whose parents have a low level of education specially their mothers, as most of their mothers are illiterate and have never been to school. Then comes those who have benefited from illiteracy classes and a few of them have been to primary school, after this category comes those whose level is junior-high school or high school. A very few of them have been to university or higher studies.

Whereas the fathers who have been to high school they come first, then comes those who have been only to primary school, then those who have been to professional formation. At the end we find fathers with junior-high school level followed by a few ones who have never been to school at all. We can say that the main cause of this confusion is the low level of education of fathers and specially of the mothers.
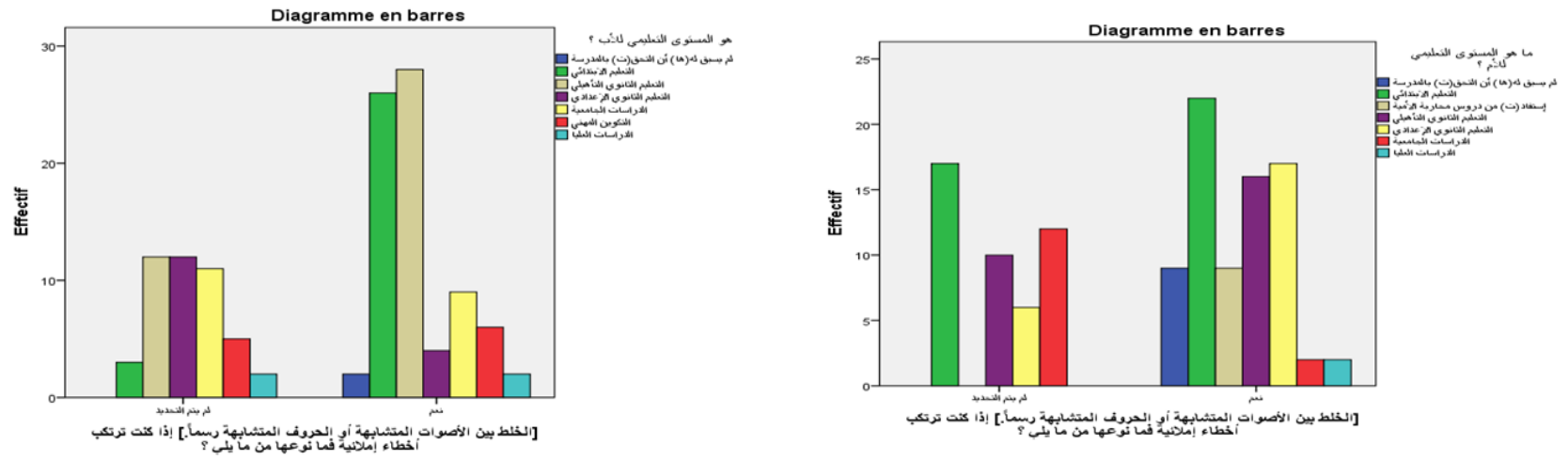

Fig. 5: the educational level of father or guardian (left) and the mother (right)

\section{Learning difficulties and educational and management practices}

We come to conclude from the figure 5 that one of the main causes of spelling mistakes is the relationship between learning difficulties and educational and management practices. This can be seen from the following figure below, as a result of the fact that the students did not benefit from primary education or kindergartens and most of them did not receive any support or assistance in reviewing the lessons. 

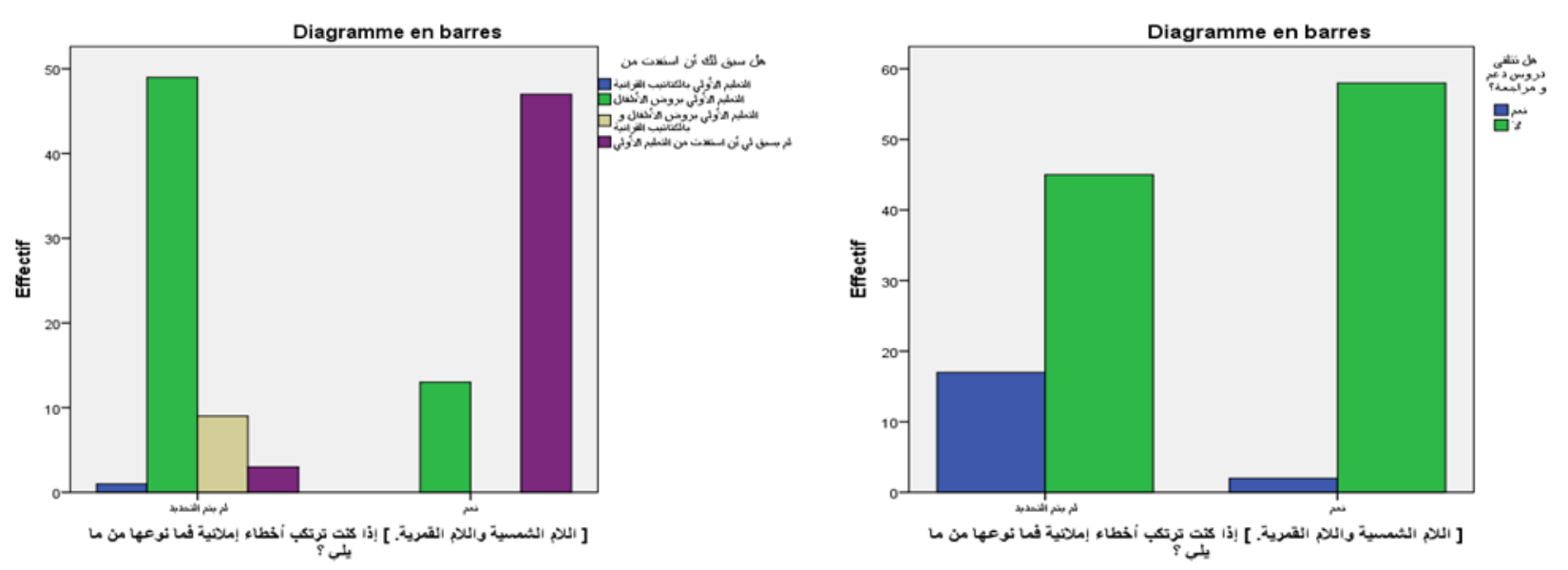

Fig. 6: Learning difficulties and educational and management practices

\section{Distance learning}

From the figure 6 we can see that $61 \%$ of students have never known about distance learning.

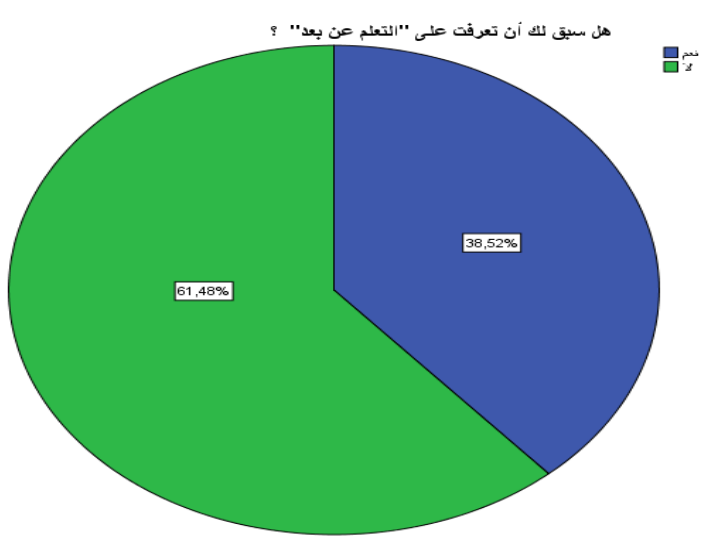

Fig. 7 knowing the distance learning

Various attempts have been made to address misspellings from different points of view. However, they did not respond to the requirements of simplicity, flexibility, and modality necessary to reach linguistic, pedagogical, educational and technical results, which led to their non-prevalence. Despite the fact that the majority of student doesn't have any idea of the elearning platform, we decided to use a Learning management system to address misspellings.

\section{E-learning solution}

Most school, worldwide, has opted for e-learning, which is considered to be the most important type of education nowadays due to its role to improve teaching and learning (Steeples, Jones, \& Goodyear, 2002). Education nowadays uses computers, tablets and smart phones to transfer the knowledge from the teacher to the learner through the internet, either by asynchronous or synchronous means.

Hence, the first benefit of e-learning is that the learner is not restricted to having a schedule or to attend the department in person to take the learning material (Sun, Tsai, Finger, Chen, $\& Y e h, 2008)$. The role of the teacher is guidance and guidance only, so the learner relies on himself to collect the required information for the material to be studied.

From there, we can show the importance of the technology that we used in our research, which are: 


\section{Arabi : Journal of Arabic Studies}

- Easy communication between the teacher and the learner at any time, even outside the classroom, to give an opport unity to the student to ask any kind of question about the school subject.

- To create groups on social media, to open a room for discussions as the limited time given to each lesson is not enough.

- It also creates a place for privacy between the student and the teacher, specially for the students that are shy or those whose level are not really good and feel afraid to ask in front of their classmate.

- The use of new technology devices to test students.

- The availability of e-books to study a subject at any time.

- The control ability that the student has on his learning and time of his study from anywhere.

\section{Choice of platform}

The choice of Moodle as our e-learning platform was conducted after comparing multiples E-learning platforms (BEKHTI, s.d.; Lecomte, 2006) among others, the study for the establishment of a distance learning system at the University of Pau Pays de l'Adour (DogbeSemanou, Durand, Leproust, \&Vanderstichel, 2012) and the one conducted by Sabin Graf (Graf \& List, 2005).

Moodle has many features:

- a very user-friendly interface with trainers, learners and administrators which makes it easy to use,

- multilingual and supports up to 40 languages,

- offers course and user management tools,

- drawing heavily on the pedagogical trend of social constructivism,

- promoting collaborative work.

\section{Creation of the platform content}

The content has been developed with a software authors "Opale" from the free software solutions suite SCENARIchain. Opale is an editorial channel for the production of academic documents that we used to create our content as a zip packages in the SCORM format (Bohl, Scheuhase, Sengler, \&Winand, 2002) to be imported into the Moodle LMS (Debacq, 2017).

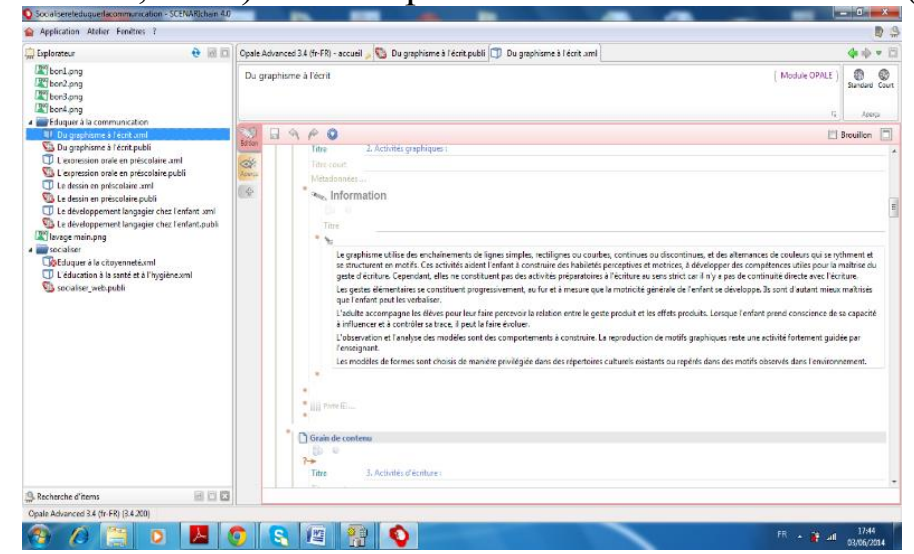

Fig. 8: Workspace ScénariChain (Opal)

\section{Presentation of the platform}

TAALIM (http://taalim-iera.ma/) is an electronic learning management system designed to provide common core students a learning platform to address their spelling errors and to provide a comfortable electronic learning environment for students. This system enables retroactive learning and provides various courses and spelling exercises. The most important features are the 
possibilities of educational design and the possibilities of control and management and the ability to manage the records of students.

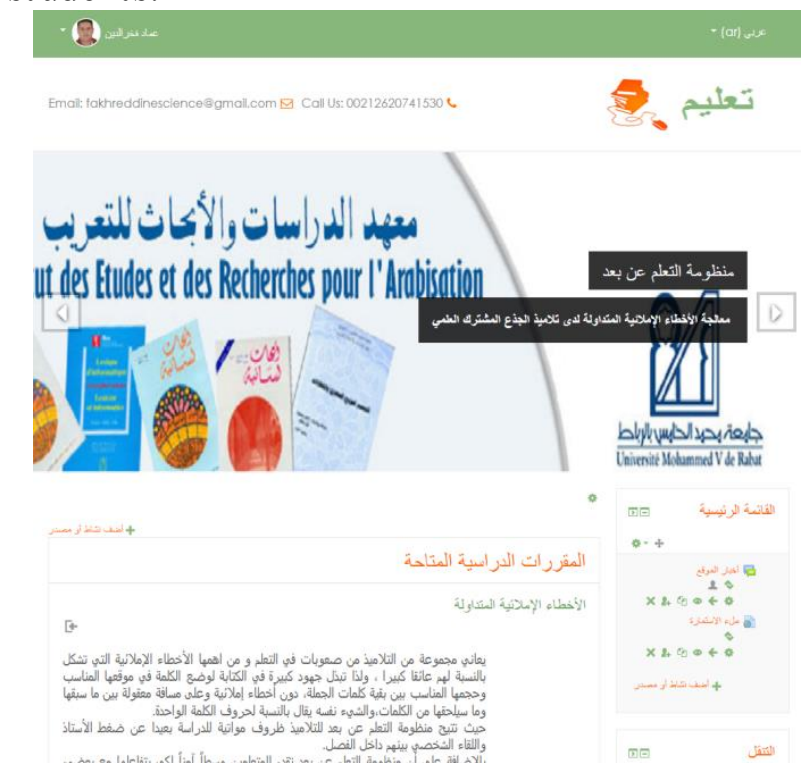

Fig. 9: The home page of the e-learning platform "TAALIM"

\section{Conclusion}

This study has enabled us to identify the most important reasons for committing spelling mistakes. Thus, we found out that the degrees of making spelling mistakes is related to the gender, class, house type and the nature of social, economic, educational and technological environment. Also the degrees of making spelling mistakes are influenced by health, mental and psychological disorder problems of the students.

We come to conclude that the learning management system that we established for the common core students has a great effect to enhance and develop the dictation skill of those students. It may also help students to make fewer mistakes or even none.

According to our research, we suggest to:

- make use of e-learning programs,

- encourage students to use e-learning programs,

- train the teachers to use e-learning programs in teaching Arabic language (listening, reading, and writing) to improve the education quality, offer DVDs in school library for students.[]

\section{References}

A.-J. Auday. 2013. "The Common Spelling Mistakes of the Students of Department of Arabic Language at College of Education, University of Karbala”, Al-Bahith Journal, Vol. 5, No. 1.

al-Ameri, Abdul Mohsen Hamad. 2015. "Common spelling errors The teachers prepare students Institutes", The islamic college university journal, Vol. 33.

Ali, A. H., \& M. A.-A.H. Al-Awfi. 2015. "The effectiveness of role-play strategy in the treatment of spelling mistakes common among elementary school students", Journal of Science and Technology, Vol. 16, No. 2.

BEKHTI, P. B. s. d.. Le choix d'une plateforme e-learning et leur rôle dans l'apprentissage et l'évaluation.

Bohl, O., J. Scheuhase, R. Sengler., \& U. Winand. 2002. "The sharable content object reference model (SCORM)-a critical review", Proceedings: International Conference on Computers in Education.

Debacq, M. 2017. La chaîne éditoriale Scenari et son intégration a Moodle, retour d'expérience. 


\section{Arabi : Journal of Arabic Studies}

Dogbe-Semanou, D., A. Durand., M. Leproust., \& H. Vanderstichel. 2012. "Étude comparative de plates-formes de formation a distance", le cadre du Projet $L$, Vol. 2.

Ellis, R. 2003. Task-based language teaching and learning. Oxford: Oxford University Press.

Graf, S., \& B. List. 2005. "An evaluation of open source e-learning platforms stressing adaptation issues", Advanced Learning Technologies, ICALT 2005.

Hamad, Imran Jassim., \& Farman Qaht Rahima. 2013. "Spelling errors common among students of colleges of education in Iraqi universities", Journal of Human Sciences, Vol. 1, No. 16.

Hammad, S. A., \& S. I. Ghulban. 2017. "Common spelling mistakes of students at Al Quds Open University / Khan Yunis Educational Zone in Arabic Course (1)”, shi, Vol. 14.

Hana, Haider Mohammed. 2012. "Common misspellings among the students of the Faculty of Quranic studies in the focal Hmzata performance and cutting", Basic Education College Magazine For Educational and Humanities Sciences, Vol. 8.

IBM. 2013. IBM SPSS statistics for windows, version 22.0. IBM Corporation Armonk.

Lecomte, B. 2006. Le choix d'un Learning Management System: une question institutionnelle.

al-Musawi, Najim A., D.dawood A. Sabree, \& Salam n. al- Gadhban. 2007. "Common spelling errors for primary school pupils From the point of view of material and teachers", Journal of Basra researches for Human Sciences, Vol. 32, No. 1 B.

Qaisi, I. A. R. 1988.Common Mistakes in Prep School Students in spelling.

Sam, A. s. d. Teaching Arabic as a communicative method: A vision in the direction of development.

Schmitz, C., \& others. 2012. "LimeSurvey: An open source survey tool", Lime Survey Project Hamburg, Germany. URL http://www.limesurvey. org.

Shibail, P. 2017. "Problems of Arabic writing, reasons for spelling errors, and methods of treatment", Journal of the Laboratory 'Research in the Language and Literature of Algeria, Vol. 13, No. 1.

Steeples, C., Jones, C., \& Goodyear, P. 2002. "Beyond e-learning: A future for networked learning", Networked learning: Perspectives and issues.

Sun, P.-C., R. J. Tsai., G. Finger., Y.-Y. Chen., \& D. Yeh, 2008. "What drives a successful eLearning? An empirical investigation of the critical factors influencing learner satisfaction", Computers \& education, Vol. 50, No. 4.

Versteegh, K. 2014. Arabic Language. Edinburgh University Press. 